\title{
연구논문
}

\section{Factors Influencing the Success of Farmers' Community Group for Rural Agricultural Development in Bali Province, Indonesia}

\author{
Dede Wahyu Fahmi Muharam \\ (Institute of International Research and Development, KNU) \\ Hwa-Soek Hwang (Institute of International Research and Development, KNU) \\ Dong-Hyun Shin (Kyungpook National University)
}

\begin{abstract}
Population growth in Indonesia is quite high, and this condition can cause an increase in poverty levels with a high level of urbanization. Rural development, which is closely related to agricultural development, can be one solution to this problem. Agricultural development in rural areas is closely related to farmers' community groups. For these reasons, such groups have a very important role in the development of rural areas and the agricultural
\end{abstract}

Author: Dede Wahyu Fahmi Muharam (Student, Institute of International Research \& Development, Kyungpook National University, Indonesia)(dewesmi@gmail.com)

Co-author: Hwa-Soek Hwang (Professor, Institute of International Research \& Development, Kyungpook National University, Korea)(hhs2129@knu.ac.kr)

Corresponding author: Dong Hyun Shin (Professor, College of Agriculture and Life Sciences, Kyungpook National University, Korea)(dhshin@knu.ac.kr)

(c) Copyright Korea International Cooperation Agency. This is an Open-Access article distributed under the terms of the Creative Commons Attribution Non-Commercial License (http://creativecommons.org/ licenses/by-nc/4.0/) which permits unrestricted non-commercial use, distribution, and reproduction in any medium, provided the original work is properly cited. 


\section{Abstract}

sector, eventually contributing to the development of the economy. This study determines the most important factors influencing the success of a farmers' community group in Indonesia. Based on the results of regression calculations with the 95\% confidence level, there are two significant variables, namely the years of operation of each community group $\left(\mathrm{X}_{2}\right)$ and the previous experience of groups as institutions (subak) $\left(\mathrm{X}_{5}\right)$. If the years of existence increases by 1 year, the score representing the success of the farmer group will increase by 7.329 points and conversely so. If the group was formerly a subak, the level of success of the farmers' community group would increase by 8.89 points.

Key words: Farmers' Community Group, Factors of Success, Rural Development, Bali, Indonesia 


\section{I . INTRODUCTION}

\section{Background}

Indonesia is the fourth biggest country in the world in terms of population. Statistics Body of Indonesia (2019) reported that the population reached 262 million people in 2017 . With positive population growth of $1 \%-2 \%$ per year, it was projected that Indonesia would be the home for inasmuch 270 million people in the year 2020. The population structure showed an expansive figure, with a higher proportion of productive ages. According to the National Development Planning Agency (2018), Indonesia will soon face a demographic bonus with these expansive figures. With almost 230 million people projected, 64\% of the population will be in the productive age of 15-64 years by 2030-2040.

The condition creates at least two critical questions. The first is how to feed the people. The second is how to create jobs for Indonesian people. These serious problems need to be handled sustainably to secure people's welfare shortly. The development of agriculture as the backbone of the economy can be the one-stop solution for critical matters. The labor force can work in the agriculture field and, at the same time, save the food production and security. However, the condition describes a different kind of path.

As much as $68 \%$ of Indonesia's labor force worked in the services and industrial sector, only $32 \%$ worked in the agricultural sector in 2016. The most obvious condition is the labor force rate working in the agricultural sector has decreased every year, shifting to other sectors, mostly to services. Even though agriculture hires a large portion of the labor force, the agriculture sector's income is still the lowest. Agriculture makes the lowest contribution to the national economy, accounting for only $14 \%$ of GDP, whereas the non-agricultural sector contributed $86 \%$ in 2017.

Based on the data from Statistics Indonesia, poverty rates in rural areas are higher than in cities. In September 2018, the percentage of urban poverty was 6.89\%. Meanwhile, the rural poverty rate reached $13.1 \%$. This phenomenon has changed the formation of Indonesia's economic sector and leads to a higher 
urbanization rate. As much as $56 \%$ of the population works in the urban areas which is only $20 \%$ of the total Indonesian area. While $44 \%$ live and work in a rural area, mostly as an agricultural worker. Statistics Indonesia even predicted that by 2040 , people living in an urban area would reach $70 \%$ of the total population.

The rural area's development would be a dynamic solution for the problems, reducing poverty and increasing equal welfare distribution. According to Ravallion and Chen, 2007, GDP growth generated by agriculture, mostly in the rural area, is up to four times in reducing poverty than growth generated by other sectors. In a longer term, the rural areas can have a bigger portion of the national economic development. The Indonesian Ministry of Agriculture formulates a set of rural development policies, which includes at least three aspects of development, namely human resources development, technological advancement and funding access improvement, and last but not least the rural institutional economics. All aspects of the development give a more significant portion to the human resources and collectively through the Institution.

In agriculture, rural human resources can be either capital or burden, depending on how well they are managed. Individual farmers have less access to resources to build their capacity to become an agent of development. However, with community groups as an institution, they will have better bargaining power, access, and capacities through cooperation and empowerment. The group can manage to supply material, sell products at better prices, provide financial sources, share knowledge and information, and many other benefits. For these reasons, the farmer's community group has a significant role in developing rural areas and the agricultural sector and, in the end, the development of the economy.

\section{Concept of Korean Saemaul Undong}

The elemental spirits of Saemaeul Undong changed the mindset and habits of the people by campaigning and instilling the spirit of "we can do it" consisting of three main slogans which are self-help (자조), diligence (근면) and cooperation (협동) among the community. The movement was initially promoted to improve 
living conditions and close the high gap of living standards between urban and rural areas that continued to be in poverty. The early stage of Saemaeul Undong focused on improving the basic living conditions and environment. The small rural area was given a fixed amount of material provided by the central Government. The villagers then, according to their needs, improved their living enviroments, such as enlarging the entrance road to the village, digging up and maintaining a public well, dredging small water-storing facilities, building a public laundry place, and so on. The later stage concentrated on a more advanced project to build rural infrastructure and to increase community income.

There were many empirical studies regarding the Saemaul Undong Movement and implementation, especially in economic development. Saemaul Undong was always identified as an integrated community based rural development program with the ultimate goal to reduce poverty in the rural area and narrowing the gap of economy, income, and development between the urban and rural areas. For instance, Park (2009) tried to update the Saemaul Undong Movement pattern with the economic condition, concept, and vocabularies that are widely known nowadays. With a qualitative approach, the study concluded that developing countries adapting the Saemaul Undong concept should carefully study their condition and adopt practical solutions to their own.

\section{Concept of Indonesia Saemaul Undong}

There were several, not many researches working on the Saemaul Undong Movement in Indonesia. They all took place in D.I Yogyakarta, one of the Province in Indonesia with a sister province relationship with Gyeongsangbuk-do, Korea. Anwar (2011) aimed to convey a reflection from Saeumaul Undong Movement in Indonesia drawn from the perspective of local stakeholders in the aspects namely spiritual foundation, the achievement of the people involved in the program, lesson learned by the local Government, and key success factors behind the current achievement of the Saemaul Undong in the D.I Yogyakarta Province. The reason for designating this particular regency was simply because of its community, village government, and local Government's enthusiasm for 
the project. Another rationale was also the fact that there were still many poor people living in the selected areas.

The objectives of the Saemaul Undong program in the rural area seems to have been achieved in several aspects. The facts were gained from interviews of stakeholders and presented in a qualitative descriptive approach. A beneficiary of the project in Batusari village said that the wells constructed during the Saemaul Undong Movement had reduced the households' expenditure for clean water. To some point, this had helped the people to use their money for other needs, instead of using it for water. A local leader of the Saemaul Undong Movement explained that better village infrastructure, particularly the roads, provided them with better access to the economic Institution (e.g., market) and social institutions (e.g., local public health service and village government services) at the sub-district office. The roads have also increased the mobility and access of the Batusari community to other villages and its rural neighborhoods. This study tended to focus on the improvement of village infrastructure.

Pramadha \& Ju (2018) stated that the adoption of Saemaul Undong in Indonesia, especially in Ponjong Village, D.I Yogyakarta Province through the Global Saemaul Undong Project, uses Village Fund Program that focuses on improving the village government authorities as policy entry. This research aimed to improve the Saemaul Undong Concept's applicability in Indonesia by reviewing and analyzing the impact of participation experience in the Global Saemaul Undong Project on participation in the Village Fund Program. A quantitative approach was used with Partial Least Square-Structural Equation Model (PLS-SEM)1) to process a data sample of 99 Ponjong villagers' opinions about their participation in the Global Saemaul Undong Project and Village Fund Program, a result of the Global Saemaul Undong Project, and their perception about Village Fund Program. In terms of participation, this research finds that Global Saemaul Undong Project has a direct positive impact on the Village Fund Program, which occurs through the synchronization of the Global Saemaul Undong Project and Village Fund Program. However, an insignificant

1) Multivariate statistical analysis models to deal with many variables and can be used for theory confirmation. 
indirect effect might indicate obstacles in realizing mindset change into participation. This study focused on the level of participation of the program and the villagers' perception and mindset.

Puspitasari et al. (2019) studied the capacity building and participatory community through the implementation of Saemaul Undong at Bleberan Village, Gunung Kidul District, D.I Yogyakarta in the perspective of sociology. Through a qualitative approach, the result showed that generally, the Saemaul Undong Movement in the Bleberan Village was well responded to. The program could better connect the relation between government and rural communities in rural agricultural development. The program also improved the spirit of self-quality development through experience and knowledge sharing. However, wider participation from the village people faced some challenges. The strategies include capacity building of rural organization, access improvement and infrastructure development, strengthening the system, and improvement of skills and incomes. One of the main findings of this study was the importance of organization or institution (rural, government, and Saemaul Undong Organization) to improve the programs' success.

Aside from these two journals, there were several informal papers regarding the Saemaul Undong Movement's topic in Indonesia, mostly from Gajah Mada University in D.I Yogyakarta Province and especially through the perspective of rural economic and sociology. All of the empirical studies showed that the implementation of the Saemaul Undong Movement positively affected the development of the rural agriculture area, even though some obstacles still occurred, especially related to culture and sociology.

\section{THEORETICAL DISCUSSION}

\section{Saemaul Undong's Success in Rural Economic Development in Korea}

Korea is a developed high-income country that has experienced remarkable success in combining rapid economic growth with significant poverty 
$\langle$ Figure 1〉 Conceptual framework

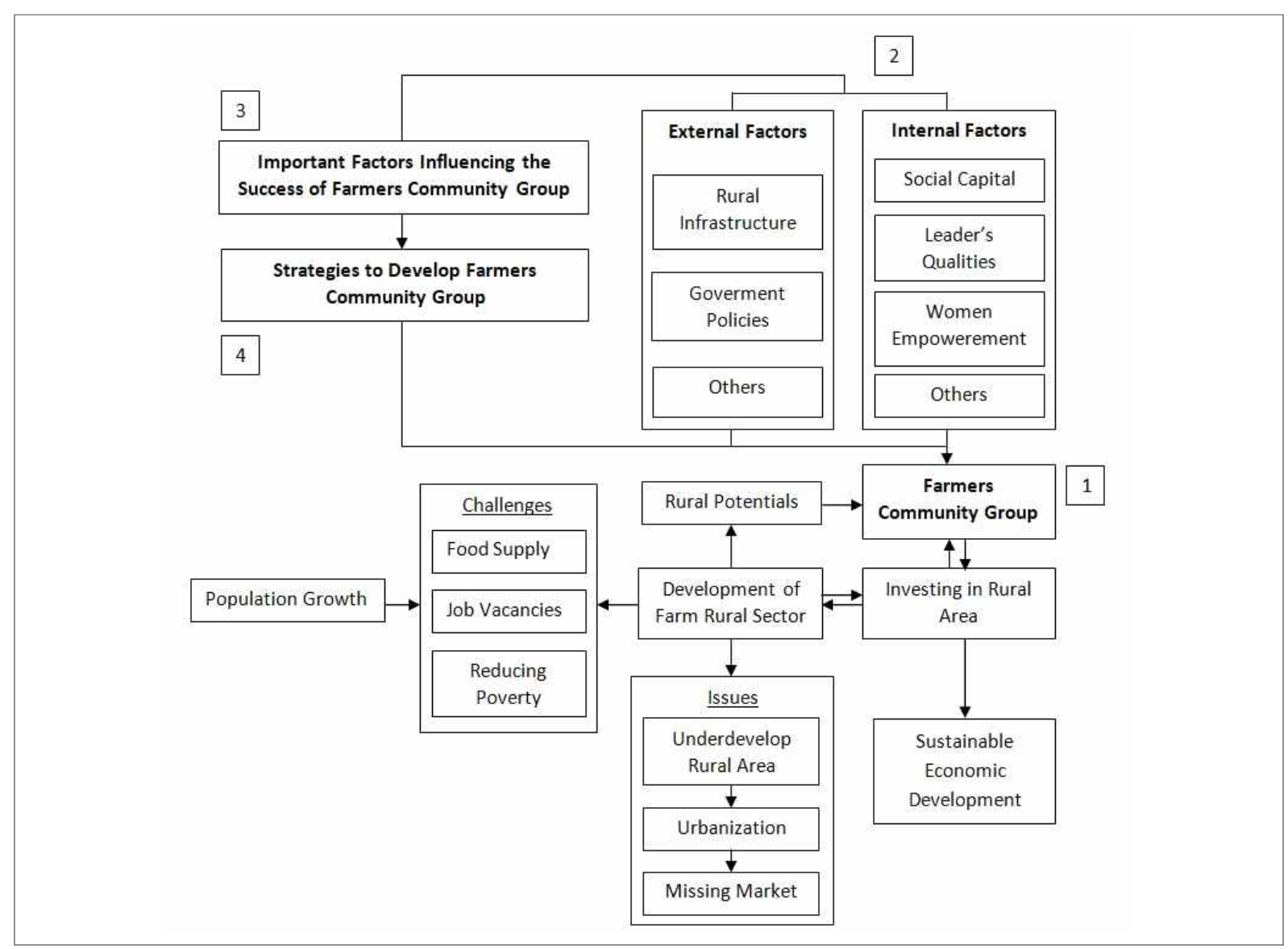

reductions. Historically, during the civil war period in 1950-1953, Korea was one of the world's poorest countries. The country's land area of 9.9 million hectares was generally hilly with nutrient-poor soils. Habitually, people only worked in spring, summer, and fall, and for the winter agricultural activities are increasingly limited. This cycle repeated over so that they were difficult to get out of poverty.

Under the leadership of President Park Chung Hee in the 1960s, the Government devised a way to improve the living standards of the population of Korea. Then in April 1970, a movement called Saemaul Undong (새마을 운동) was introduced. It consists of three words: 새 (se) means new, 마을 (maeul) means village or community, and 운동 (undong) means movement. In other words, Saemaeul Undong is a movement for rural development and reform towards a better life (Understanding Saemaul Undong, 2019) Saemaeul Undong has been recognized by the United Nations and several international organizations as an effective development model, proven to reduce poverty levels in rural areas. 
According to World Bank (2020). With GDP growth averaging 10\% annually between 1962 and 1994, nowadays, Korea is the world's 15th largest economy in the world. Korea's sustainable development experience, providing infrastructure and better services to improve people's lives from Saemaeul Undong, and its transition to a dynamic knowledge economy provides lessons that can benefit many other developing countries.

\section{Factors for the Success of Saemaul Undong in Korea}

In the Saemaul Undong Movement, rural villages are the smallest development unit. It also paid much attention to the involvement of women and the young generation. This concept is in sync with the rural agricultural development led by the Indonesian Government. However, adapting the success of the Saemaul Undong Movement to the success of the farmer's community group in Indonesia was only fractionally done.

There were at least three major conditions that contributed to the success of Saemaeul Undong, as shown in 〈Figure 2〉. The first was because of nationwide participation. The nationwide participation was the stepping stone of the Saemaul Undong Movement. The Central Government initiated this movement and therefore had the characteristic of the top-down policy. Therefore, the strong leadership and commitment among the stakeholders. This initiative includes the participation of women and the younger generation, which was a particulalry valuable asset in achieving the ultimate common goals.

The second was the motivation for the stakeholders to participate in the projects of Saemaeul Undong. These factors include the arrangement from Government, including the importance of competitive atmosphere, well-selected projects including projects related to income generation, and operating the villages as the development units. The third was arranging the projects such as classifications of villages, their suitable development and type of government assistance, and project expansion by zone.

Even though Saemaeul Undong gained success especially in the early stage there were some critical views on SMU: 
1) As SMU was mostly initiated and led by the Government, it sometimes prevented residents from using creativity and spontaneity. Some projects were criticized as being mere window dressing. However, the top-down process was inevitable as SMU was a nationwide campaign targeting over 36,000 rural areas all at the same time. Some criticized that SMU in the 1970s was a mere quantitative revolution.

2) Excessive competition for better performance among rural areas and local governments tended to lead to unnecessary projects.

3) Most of the projects were dependent on government assistance, and some projects could not be carried out without government support.

4) Some viewed that the success of the Saemaul Undong Movement only happened in the first phase, while it was less effective after Korea entered a more industrialized stage.

〈Figure 2〉 Factors contributing to the success of Saemaul Undong

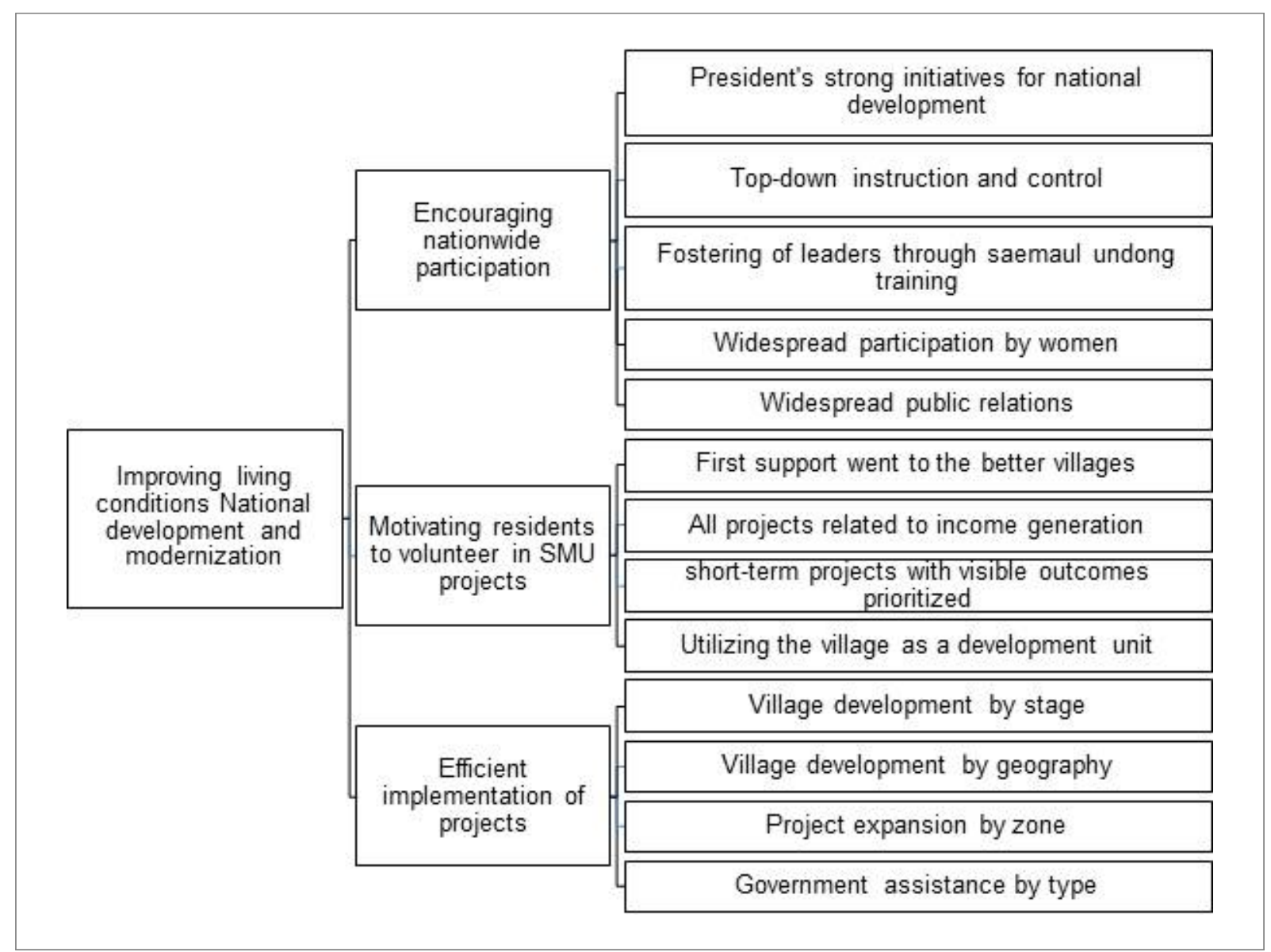

Source: Understanding Saemaul Undong, 2019. 


\section{Factors for the Success of Saemaul Undong in Indonesia}

There were several empirical studies regarding the success factors of farmer groups in certain Provinces in Indonesia. Hariadi (2004) studied the factors influencing the success of farmer groups as business units. The area coverage was Gunung Kidul, a regency in Central Java Province. The success of groups as business units generally evidenced in the middle and main class of farmer groups, with the conduct of certain activities: agricultural equipment rental (sprayer, and diesel water pump machine.), stalls owned by the group, cooperatives owned by the group, livestock/fisheries owned by the group, partnership with companies.

The method of survey was used targeting groups as its unit of analysis. The sample was taken from 90 groups by stratified random sampling. Each group is represented by five members: one member of the board, two active members, and two regular members. The resulting data were then analyzed using multiple regression from the SPSS computer program. Later on, the analysis was developed through path analysis using the Amos computer program.

The result showed three factors out of eight factors observed that contributed significant value to farmer groups' success as a business unit. The influential factors were: self-efficacy of the members of the groups, interaction among members, and the leadership style of the chairman of groups. Through path analysis, it is shown that the biggest influence on farmer groups' success as a business unit was the self-efficacy or self-confidence. It can be concluded that the group leader's leadership played an important role because leadership style suited to the conditions of the members could directly influence the success of business activities. Indirectly the leadership also could help to promote selfefficacy among members.

Interaction among members also plays an important role in group development as a business unit. Interactions occur regularly through monthly meetings, community services, and cooperative activities. The learning and coordination process takes place, both from the instructor, experience, and social learning. This learning process and coordination is a dynamic process for developing insight, knowledge, and skills. Interaction between group members is a vital part of achieving a common goal. 
This research was systematically arranged, and a suitable methodology was used. However, simultaneously, the model used the same variables or factors as used by other previous researches, which makes the result predictable. The variables observed tended to belong to institutional aspects rather than organizational. Moreover, this made the recommendation regarding the significant factors are unique and not feasible to be adopted in general.

According to another research analyzing the factors that influence the success or performance of farmer groups, it is concluded that the ability of farmer groups in rainfed areas is influenced by various factors that have a statistically significant effect: years of operating farmers' community groups, the size of land owned by each farmer group, age of leader of the farmer group, number of positions of head of the farmer group, age, and status of agricultural extension services. This research was conducted (Djamhuri and Rina, 1994) in Tapin District, South Kalimantan Indonesia. This research used a survey sampling method and data processing method, which is done by multiple regression analysis.

\section{Farmers Community Organization in Indonesia}

Historically, farmers in Indonesia naturally formed their institutions. These kinds of institutions are genuinely informal, such as a subak institution in Bali Province. The Institution includes three aspects: normative, regulative, and cultural-cognitive, including norm, regulation, cooperation, and bound. There were also aspects of the organization, such as leader, common interest, and annual meeting. According to the Bali Provincial Regulation No. 9 (2012), subak is a traditional organization in water use and or records at the farm level of indigenous peoples in the Province of Bali. It is a socio-agrarian, religious, economic organization, which has historically continued to grow and develop.

Farmer groups are defined as a collection of farmers consisting of adult farmers (male or female) of youth farmers (young men or women), who are informally bound in a group are based on harmony and common needs, common interests, shared environmental conditions (social, economic, resources) and cooperation based on familiarity to improve and develop the 
members' business and welfare (Law of the Republic Indonesia no 19, 2013). According to the revision of The Decree of Head of Agricultural and Human Resources Development, the level of a farmers' group is measured based on each group's outputs and / or outcomes of five simultaneous aspects, namely: Planning, Organizing, Actuating, Controlling and Leadership development (Decree of Head of Agricultural and Human Resources Development Ministry of Agriculture Republic of Indonesia, 2011).

The measurement score given to the farmer's community group by the ministry of agriculture is based on the farmer's community group performance for the last 2 (two) years, with aspects of the assessment, including:

1) Institutional Administration Aspects (200 points)

2) Planning Aspects (150 points)

3) Activity Implementation Aspects (350 points)

4) Development and Supervision Aspects (200 points)

5) Business Development Report Aspects (100 points)

Following the results of the measurement, the farmers' groups are classifed into four classes:

1) Beginner (with a score $\leq 245$ points)

2) Intermediate (with a score between $246-455$ points)

3) Advanced (with a score between 456-700 points)

4) Main (with a score between $700-1,000$ points)

These four classes represent the maturity and the ability of the farmer groups to develop the benefit and the organization itself. The higher the class or even the score, the more it is considered a better organization capable of developing towards economization. However, some criticism also has been raised. One of the most important things is that sometimes a group with a high score or high class lacks essential things such as dynamics. However, at the same time, it is also debatable. Therefore, for this study, the result of measurement alone is not enough to determine a farmer's community group's success. Qualitative assessment from knowledgeable authority can be approved for complete measurement. 


\section{Problem Statement and Limitations of the Study}

Farmer's community group is a form of cooperation and consolidated agriculture between the members to achieve common goals, mainly to increase productivity, income, and welfare. Some farmer's community groups achieve success, but some failed. In 2014, it was estimated that around 20\% of farmer's community groups had failed (Directorate General of Post Harvest and Marketing, 2014). The knowledge about reasons and factors influencing farmers' community groups' success can be essential for implementing a suitable strategy for rural and agriculture development.

There are some limitations in this research, due to a huge number of farmers' community groups in Indonesia. It is recorded that in 2019 there are approximately 480,080 farmer's community groups categorized, spread out in 34 provinces in Indonesia. The distribution based on Province shows that as much as two-thirds of the total were in the 'beginner' class and more than a quarter of the total were in the 'intermediate' class. Only less than $6 \%$ belong to 'advanced' and 'main' classes.

Among the 34 provinces, Bali has the highest percentage of 'advanced' and 'main' class of farmer's community group. Another program such as Indonesian youth farmers is targeted to be developed in Bali, involving 514 farmers community groups in 2019. This makes Bali marked as the most successful province so far, in terms of enhancing the development of the farmer's community group. Therefore, Bali Province is chosen to be the sample Province for this study.

\section{Rural Organization or Institution in the Perspective of Sociology}

Although institutions and organizations are often understood as the same, the two are different in sociology terms. Horton \& Chester (1984) described that institutions tended to be more traditional, while organizations be more modern. Therefore, institutions' changes take a long time and at a slower pace than the more dynamic and fast-changing features of the organization. Corresponding to 
the opinion also, Binswanger et al. (1978) stated that an institution is defined as the set of behavioral rules that govern a particular pattern of section and relationship while an organization generally is seen as a decision-making unit that exercises control of resources. Syahyuti (2014) stated that the Institution refers to both abstract and concrete entities; meanwhile, the organization refers to physical entities.

The Institution is usually bottom-up, raised from society, and therefore public-driven. In contrast, the organization is top-down, policy, or arrangement from the authority and Government or authority driven. Therefore, the change in institution takes longer time and slower pace, while organization tends to be more dynamic. This argument came from different sources, at least: Tjondronegoro (1999), Hayami \& Kikuchi, (1987), and Brewer (1985). Therefore the aspects of Institution and Organization might be different. As in Scott (2008), aspects of institutions refer to the norm, regulation, and cultural cognition. These aspects are more abstracts, unique, and fundamental at the same time. Meanwhile, aspects of organization refer to membership, leadership, rules in the organization, structure, capacity, goals, and finance. The aspects are more visible, more measurable, and structurally clearer.

Therefore, according to Uphoff (1986), the Institution needs to be organized, and the organization needs to be institutionalized. According to this literature, both institutions and organizations are in one continuum, with the ultimate goal is either an institutionalized organization or an organized institution. This argument was also in sync with Huntington and Samuel(1965). The summary of the diffences between institution and organization discussed above are shown in 〈Table 1〉.

Referring to the literature, the Indonesian farmer's community group is a form of organization. The Ministry of Agriculture regulates the formation alongside other agriculture organizations: Gapoktan, agricultural commodity association, and national agricultural commodity board.

At the same time, some institutions were already established well in the rural area. One of them is Subak. Subak is a traditional Bali farmers institution that mainly aims to share responsibilities in managing water irrigation and rice planting patterns in rice fields. Subak, as a farmer-based irrigation system, is an 


\section{$\langle$ Table 1〉 Differences between institution and organization}

\begin{tabular}{|c|c|c|}
\hline No & Institution & Organization \\
\hline 1 & Tend to be more traditional. & Tend to be more modern. \\
\hline 2 & $\begin{array}{l}\text { Usually bottom-up, raise from society. } \\
\text { Public driven. }\end{array}$ & $\begin{array}{l}\text { Top-down, policy or arrangement from } \\
\text { the authority. Government or authority } \\
\text { has driven. }\end{array}$ \\
\hline 3 & The Institution needs to be organized. & $\begin{array}{l}\text { The organization needs to be } \\
\text { institutionalized. }\end{array}$ \\
\hline 4 & $\begin{array}{l}\text { Defined as the set of behavioral rules } \\
\text { that govern a particular pattern of } \\
\text { section and relationship. }\end{array}$ & $\begin{array}{l}\text { Generally seen as a decision-making unit } \\
\text { that exercises control of resources. }\end{array}$ \\
\hline 5 & $\begin{array}{l}\text { Institution refers to both abstract and } \\
\text { concrete entities. }\end{array}$ & Organization refers to physical entities. \\
\hline \multirow[t]{2}{*}{6} & $\begin{array}{l}\text { Aspects of institutions refer to the } \\
\text { norm, regulation, and cultural cognitive. }\end{array}$ & $\begin{array}{l}\text { Aspects of organization refer to } \\
\text { membership, leadership, rules in the } \\
\text { organization, structure, capacity, goals, } \\
\text { and finance. }\end{array}$ \\
\hline & $\begin{array}{l}\text { The aspects are more abstracts, unique } \\
\text { and fundamental at the same time. }\end{array}$ & $\begin{array}{l}\text { The aspects are more visible, more } \\
\text { measurable, and structurally clearer. }\end{array}$ \\
\hline 7 & $\begin{array}{l}\text { The change in the Institution takes a } \\
\text { longer time and at a slower pace. }\end{array}$ & More dynamic and more fast-changing. \\
\hline
\end{tabular}

independent and democratic institution. The main building of subak is irrigation channel building. According to Dewi et al. (2018), Subak is a traditional organizing institution in agriculture based on art and culture. It is inherited from generation to generation by the people on the Island of the Gods. Subak is a social institution that specifically regulates the irrigation system used in rice farming in Bali.

According to the Bali Provincial Regulation No. 9 (2012), subak is a traditional organization or Institution in water use and or records at the farm level of indigenous peoples in Bali that are socio-agrarian, religious, economic, which historically continues to grow and develop. With these criteria, Subak is socalled "institution". The many existing Subak are administratively organized to be farmer's community groups. 


\section{Hypothesis}

Based on the discussion above, the hypothesis so far for this research are concluded:

1) The age of the leader has a significant negative effect on the farmer's community group's success.

2) The year of existence significantly has a positive effect on the success of farmer's community groups.

3) Both gender participation significantly has a positive effect on the success of the farmer's community group. The farmer's community group, with both gender participation, regardless of the proportion.

4) The size of the farmer's community group is based on the number of members.

5) The previous existence of a farmer's community group as an institution (Subak) has a significant positive effect on the farmer's community group's success.

6) The participation of farmer's community groups in Gapoktan has a significant positive effect on the farmer's community group's success.

7) The dedication of members of the farmer's community groups has a significant positive effect on the farmer's community group's success.

8) The infrastructure of each farmer's community groups has a significant positive effect on the farmer's community group's success.

\section{METHODOLOGY OF RESEARCH FARMERS COMMUNITY GROUP IN BALI INDONESIA}

\section{Types, Characteristics, and Population of Research}

This type of research uses secondary data which is a database of objects owned by the Ministry of Agriculture of the Republic of Indonesia compiled by experts in their fields, namely agricultural extension personnel on institutions or 
farmers community groups, and using literature research the collection of data obtained through data sources from several kinds of literature related to the themes of the research object.

The character of this research uses qualitative and quantitative methods, namely research that intends to understand the phenomena about what is experienced by the object of research characteristics, such as farmer group classes, number of members, and gender. This study departs from the data in the form of numbers to analyze what they want to know and by utilizing existing theories as explanatory material. The meaning behind the data is understood to find the truth either empirically or logically.

The population is a generalization area consisting of objects/subjects with specific qualities and characteristics determined by researchers to be studied and then drawn conclusions. Meanwhile, the population is the whole object of research. Whereas in this study, the total population of the study is the number of Farmer Groups in all Bali Province regions consisting of 11,037 farmer groups. In this study, do not use samples. The researcher took the entire population as a sample, so this study is a population study.

\section{Research Variable}

Research variables are everything that is the object of research observations that are. Targeted variables are phenomena that are the center of research attention to be observed or measured. In this study, there are independent variables and dependent variables.

The data used in this study were secondarily obtained from the portal of Simluhtan (Agricultural Information Dissemination System) Ministry of the Agriculture Republic of Indonesia. The portal was made in 2015 for a database of farmer's community groups in Indonesia. The data was updated regularly and was on schedule to be upgraded at the end of the first quarter of 2020, the Ministry's new administration year. Due to the case of Covid-19 in Indonesia, some of the data cannot be obtained and become the subject of the adjustment or limitation to this study. 
Independent variables are variables that affect or are called independent variables. The independent variables in this study are:

1) Age of leader $\left(X_{1}\right)$

2) Year of existence farmer's community groups $\left(X_{2}\right)$

3) Combination of the woman and man participation(Dummy) $\left(X_{3}\right)$

4) Number of members $\left(X_{4}\right)$

5) Subak or non-subak (Dummy) $\left(\mathrm{X}_{5}\right)$

6) Join farmers' group's association (Gapoktan) or not join (Dummy) $\left(\mathrm{X}_{6}\right)$

7) Dedication of members to each farmer's community groups (Dummy) $\left(X_{7}\right)$

8) The infrastructure of each farmer's community groups (Dummy) $\left(\mathrm{X}_{8}\right)$

The dependent variable is the variable affected or depends on other variables because of the independent variables. The dependent variable in this study is the class of farmers group in Bali Province, Indonesia. The indicator is the evaluation score conducted by the Ministry of Agriculture of the Republic of Indonesia.

There were seven variables used to describe Farmer's community groups' organizational factors, as presented in the 〈Table 2$\rangle$.

\section{〈Table 2〉 Factors of farmer's community groups}

\begin{tabular}{|l|l|l|l}
\hline No. & \multicolumn{1}{|c|}{ Data } & Variable & \multicolumn{1}{|c}{ Explained as } \\
\hline 1 & $\begin{array}{l}\text { The score of each farmer's } \\
\text { community groups }\end{array}$ & $Y$ & $\begin{array}{l}\text { Describe the level of success of the } \\
\text { farmer's community group. The higher the } \\
\text { number, the more successful the group } \\
\text { considered. }\end{array}$ \\
\hline 2 Age of leader & $X_{1}$ & $\begin{array}{l}\text { The participation of a young leader is } \\
\text { expected to increase the possibility of the } \\
\text { farmer's community group's success. At } \\
\text { the same time, a young leader would } \\
\text { encourage other youth to participate in } \\
\text { rural development. According to WHO, } \\
\text { youth is described as productive age of } \\
18-65 \text { years old. But according to UU No. } \\
40 \text { Tahun 2019, the young people of } \\
\text { Indonesia range between 18-30 years old. }\end{array}$ \\
\hline
\end{tabular}




\section{〈Table 2〉 Continued}

\begin{tabular}{|c|c|c|c|}
\hline No. & Data & Variable & Explained as \\
\hline 3 & $\begin{array}{l}\text { The year of existence of } \\
\text { each farmer's community } \\
\text { groups }\end{array}$ & $X_{2}$ & $\begin{array}{l}\text { The year of existence would explain the } \\
\text { experience of the farmer's community } \\
\text { group. The longer the existence, to some } \\
\text { extent, would give more time for the } \\
\text { group to gain experience and success. }\end{array}$ \\
\hline 4 & $\begin{array}{l}\text { Woman and man } \\
\text { Participation in each } \\
\text { farmer's community groups }\end{array}$ & $X_{3}$ & $\begin{array}{l}\text { Dummy variable. The participation of both } \\
\text { gender in the groups would balance their } \\
\text { role to the success of the group. The } \\
\text { groups with both gender as their member } \\
\text { would receive "1" as the score, and the } \\
\text { groups with only one kind of gender would } \\
\text { receive "0" as the score. }\end{array}$ \\
\hline 5 & Number of members & $X_{4}$ & $\begin{array}{l}\text { Members are assets for the organization, } \\
\text { and they can contribute to the progress of } \\
\text { the farmer community organization. }\end{array}$ \\
\hline 6 & $\begin{array}{l}\text { The previous existence of } \\
\text { farmer's community group } \\
\text { as an institution }\end{array}$ & $X_{5}$ & $\begin{array}{l}\text { Dummy variable. If the farmer's } \\
\text { community group were previously an } \\
\text { informal institution in the society, in this } \\
\text { case, "subak", it would be given "1" as the } \\
\text { score. If the farmer's community group } \\
\text { had no form of the Institution previously, it } \\
\text { would be given "0" as the score. }\end{array}$ \\
\hline 7 & $\begin{array}{l}\text { The participation of Join } \\
\text { farmers' group's } \\
\text { association (Gapoktan) }\end{array}$ & $X_{6}$ & $\begin{array}{l}\text { Dummy variable. The participation of a } \\
\text { farmer's community group in a larger } \\
\text { organization would give more access to } \\
\text { information, knowledge, profitable } \\
\text { opportunity, and so on. Positive } \\
\text { participation of farmer's community group } \\
\text { would receive "1" as the score while } \\
\text { non-participation would receive "0" as the } \\
\text { score. }\end{array}$ \\
\hline 8 & $\begin{array}{l}\text { Dedication of members to } \\
\text { each farmer's community } \\
\text { groups }\end{array}$ & $X_{7}$ & To be omitted. Data not available. \\
\hline 9 & $\begin{array}{l}\text { The infrastructure of each } \\
\text { farmer's community groups }\end{array}$ & $X_{8}$ & To be omitted. Data not available. \\
\hline
\end{tabular}




\section{Methods of Collecting Data and Analysis}

This data collection method uses document material because, in this case, the researcher does not directly retrieve the data but utilize existing data or documents, which are database of farmer groups owned by the Ministry of Agriculture of the Republic of Indonesia. In this case, secondary data from farmer groups are primary data obtained by the Ministry of Agriculture or primary data that has been further processed and presented by the Ministry of Agriculture in tables. This study also conducted literature research, where data was obtained from various literature to obtain information or data relating to this study, like the journals and previous research.

To find out how much influence the Age of the leader $\left(\mathrm{X}_{1}\right)$, year of existence farmer's community groups $\left(\mathrm{X}_{2}\right)$, combination woman and man participation (dummy) $\left(\mathrm{X}_{3}\right)$, number of members $\left(\mathrm{X}_{4}\right)$, subak or non-subak (dummy) $\left(\mathrm{X}_{5}\right)$, and join farmers' group's association or not join (dummy) $\left(\mathrm{X}_{6}\right)$ on the dependent variable, in this case, are the score class of farmers groups. Then multiple linear regression statistical tests are used. The multiple linear regression statistical test is used to test whether or not the relationship between more than two variables is significant through its regression. Multiple linear regression involves more than two variables, namely one dependent variable $(\mathrm{Y})$ and more than two independent variables. The tool used to do multiple linear regression in this study is SPSS software for windows.

In addition to multiple linear regression, this study also uses dummy regression. 2) Another name for dummy regression is category regression. This regression uses a qualitative predictor (which is not a dummy called a quantitative predictor). Dependent variables can be influenced by quantitative independent variables and made possible by qualitative variables. The qualitative variables must be quantified attributes (characteristics). To quantify a qualitative variable's attributes, a dummy variable is formed with values " 1 " and "0". So, this is what is meant by the dummy variable. A value of "1" indicates the presence, while a value of " 0 " indicates the absence of these quality charac-

2) Dummy variables are variables used to quantify the qualitative variables (e.g., gender) which are categorical which are thought to have an effect on dependent variables. 
teristics, for example, gender variables. If the value " 1 " is used for men, then the value " 0 " indicates not a male (female), or vice versa.

Mathematically can be expressed in the form of general functions, where the score class farmers groups $(\mathrm{Y})$ is a function of the age of leader $\left(\mathrm{X}_{1}\right)$, year of existence farmer's community groups $\left(\mathrm{X}_{2}\right)$, a combination of woman and man participation (dummy) $\left(\mathrm{X}_{3}\right)$, number of members $\left(\mathrm{X}_{4}\right)$, subak or non-subak (dummy) $\left(\mathrm{X}_{5}\right)$, and join farmers' group's association or not join (dummy) $\left(\mathrm{X}_{6}\right)$. The equation model can be described as follows:

$$
Y=f\left(X_{1}, X_{2}, X_{3}, X_{4}, X_{5}, X_{6}\right)
$$

Furthermore, Equation (1) above is transformed into multiple regression, as follows:

$$
Y=\beta_{0}+\beta_{1} X_{1}+\beta_{2} X_{2}+\beta_{3} X_{3}+\beta_{4} X_{4}+\beta_{5} X_{5}+\beta_{6} X_{6}+\varepsilon
$$

Then the above equation function is converted into the form of multiple linear regression and ordinary least square, as follows:

$$
\begin{aligned}
\operatorname{Ln} Y= & \operatorname{Ln} \beta_{0}+\beta_{1} \operatorname{Ln} X_{1}+\beta_{2} \operatorname{Ln} X_{2}+\beta_{3} \operatorname{Ln} X_{3}+\beta_{4} \operatorname{Ln} X_{4}+\beta_{5} X_{5}+\beta_{6} X_{6} \\
Y= & \text { Score class farmers group } \\
X_{1}= & \text { Age of leader farmers' groups } \\
X_{2}= & \text { Year of existence farmer groups } \\
X_{3}= & \text { Combination woman and man participation } \\
& \text { (combination }=1 \text {, non combination }=0) \\
X_{4}= & \text { Number of members } \\
X_{5}= & \text { Subak or non subak (subak }=1 \text {, non subak }=0) \\
X_{6}= & \text { Join farmers' groups asociation or not join }(\text { dummy) } \\
& \quad \text { (join }=1, \text { non join }=0) \\
\beta_{0}= & \text { Constanta } \\
\beta_{1} \beta_{2} \beta_{3}= & \text { Parameter or regression coefficient } \\
\varepsilon= & \text { Error }
\end{aligned}
$$


This test is used to determine whether each independent variable individually has a significant influence on the dependent variable. In other words, to find out whether each independent variable can explain the changes that occur in the dependent variable significantly.

Tests carried out by comparing the values of $\mathrm{t}$-count obtained from the coefficient table with an error rate of $5 \%(a=0.05)$ and a degree of freedom (df) of $(n-k)$ with the provisions of decision making If $\mathrm{f}$-count $\left\langle\mathrm{f}\right.$-table then $\mathrm{H}_{0}$ is accepted and $H_{1}$ is rejected (not significant). If $\left.f-c o u n t\right\rangle f-t a b l e$, then $H_{0}$ is rejected, and $\mathrm{H}_{1}$ is accepted (significant).

\section{RESULT OF RESEARCH ON FARMER'S COMMUNITY GROUP IN BALI INDONESIA}

\section{General Description of Bali Province}

Land in the Province of Bali is mostly for agriculture in a broad sense. The land allocation based on its use can be specified as follows: 78,626 hectares of paddy land area (99\% irrigated paddy land, and 1\% of rainfed land), 123,774 hectares of plantations, 122,127 hectares of plantations others, and pool 3,800 hectares.

In the Province of Bali, farmer groups, or also called subak as a regional term, function as a unit or vehicle for learning, cooperation, production, and other economic business activities. There are 11,037 farmer groups in Bali Province, consisting of 1,255 Beginner class farmer groups, 5,473 Intermediate class farmer groups, 4,124 Advanced class farmer groups, 185 Main class farmer groups.

\section{Factors Influencing the Success of Farmer's Community Group}

The data started from the population of 11,037 farmer groups in Bali Province. From the 11,037 observations, there were 5,522 observations with incomplete data, which covered $50.03 \%$ of the whole population. Omitting the incomplete 
data left off the remaining 5,515 observations to be processed. However, the data distribution showed as much as 500 observations (4.53\%) were outliers. Therefore inasmuch as 5,015 observations (45.44\%) were finally obtained to be further analyzed.

This analysis is used to see the relationship between variables in the farmer group and the level of success or class of the farmer group, so it is expected to be a guide or strategy to develop the farmer's community group in rural agriculture areas. This analysis considers aspects of the socio-cultural traditions prevailing in the Balinese farming community. The variables that are thought to influence the success rate of this farmer group are the age of the leader, the year of existence of the farmer's community group, a combination of female and male participation, the number of members, subak or non-subak, and joining a farmer group association or not join.

The relationship between variables in the farmer group and the farmer group's level of success or class is modeled into a multilinear regression equation using the Ordinary Least Square (OLS) estimator method. The farmer group's class or score is the explained variable or dependent variable (Y), while the variable in the farmer group is the explaining variable or independent variable (X). Factors or variables in the farmer group included in the model include the age of leader $\left(\mathrm{X}_{1}\right)$, the year of existence of the farmer's community group $\left(\mathrm{X}_{2}\right)$, a combination of female and male participation $\left(\mathrm{X}_{3}\right)$, number of members $\left(\mathrm{X}_{4}\right)$, subak or non-subak $\left(\mathrm{X}_{5}\right)$, and join a farmer group association or not join $\left(\mathrm{X}_{6}\right)$. Farmer group variables that are thought to influence the level of success or class of the farmer group are not included in the model. Only variables that are available and meet the requirements can be included in the model and used as independent variables to analyze thought to influence farmer groups' success. Dedication of members to each farmer's community groups does not become an independent variable due to data unavailability in the farmer groups' database, owned by the Ministry of Agriculture of the Republic of Indonesia. The infrastructure of each farmer's community groups in each village is not used as an independent variable in the calculation of the model because none of the villages in the Province of Bali currently belong to the lagging category (Bali 
statistics, 2019), so it is assumed that infrastructure is well and evenly available throughout the Province of Bali.

As for estimation results or multiple linear regression calculations regarding Influencing the Success of Farmer's Community Group Factors for Rural Agricultural Development in Bali Province, Indonesia includes the previous existence of farmer's community groups as an institution, the year of existence of each farmer's community groups, women and man participation in each farmer's community groups, the participation of join farmers' group's associations (Gapoktan), age of leaders, and the number of members are as follows $\langle$ Table 3$\rangle$.

Regression of model equation:

$$
\begin{aligned}
\hat{\mathrm{Y}}= & \alpha+\beta_{1}\left(\mathrm{X}_{1}\right)+\beta_{2}\left(\mathrm{X}_{2}\right)+\beta_{3}\left(\mathrm{X}_{3}\right)+\beta_{4}\left(\mathrm{X}_{4}\right)+\beta_{5}\left(\mathrm{X}_{5}\right)+\beta_{6}\left(\mathrm{X}_{6}\right) \mathrm{e} . \\
\mathrm{Y}= & 278.501+0.207\left(\mathrm{X}_{1}\right)+7.329\left(\mathrm{X}_{2}\right)-1.008\left(\mathrm{X}_{3}\right)+0.063\left(\mathrm{X}_{4}\right)+8.887\left(\mathrm{X}_{5}\right)+ \\
& 0.265\left(\mathrm{X}_{6}\right)
\end{aligned}
$$

\begin{tabular}{|c|c|c|c|}
\hline Variable & Coefficient & T-statistics & $p$-value \\
\hline Constants (C) & 278.501 & 35.090 & .000 \\
\hline Age of leader $\left(X_{1}\right)$ & .207 & 1.315 & .189 \\
\hline $\begin{array}{l}\text { The year of existence of each } \\
\text { farmer's community groups }\left(X_{2}\right)\end{array}$ & 7.329 & 78.142 & .000 \\
\hline $\begin{array}{l}\text { Woman and man participation in } \\
\text { each farmer's community } \\
\text { groups/combination gender or non } \\
\text { combination Gender }\left(X_{3}\right)\end{array}$ & -1.008 & -.379 & .704 \\
\hline Total number of members $\left(X_{4}\right)$ & .063 & .930 & .352 \\
\hline $\begin{array}{l}\text { The previous existence of farmer's } \\
\text { community group as an } \\
\text { institution/Subak or non-Subak }\left(X_{5}\right)\end{array}$ & 8.887 & 3.099 & .002 \\
\hline $\begin{array}{l}\text { The participation of Join farmers' } \\
\text { group's association/Gapoktan or } \\
\text { non-Gapoktan }\left(X_{6}\right)\end{array}$ & .265 & .101 & .920 \\
\hline$N=5,015$ & $R^{2}=.555$ & $\begin{array}{c}\text { F-statistics }= \\
1,042.643\end{array}$ & $F($ sig $)=.000$ \\
\hline
\end{tabular}

〈Table 3〉 Results of analysis of factors influencing the success of farmer's community group to Rural Agricultural Development in Bali province, Indonesia 


\section{Analysis of Factors}

Based on the results of regression calculations between the previous existence of farmer's community groups as an institution, the year of existence of each farmer's community groups, woman and man participation in each farmer's community groups, the participation of join farmers' group's associations (Gapoktan), age of leader, and Number of members, success of farmer's community group (Y) level. The value of $\mathrm{R}^{2}=0.555$ is obtained, indicating that the variation in the change in the value of the level of Success of farmer's community group $(\mathrm{Y})$ can be explained simultaneously by the previous existence of farmer's community group as an institution, the year of existence of each farmer's community groups, women and man participation in each farmer's community groups, the participation of join farmers' group's associations (Gapoktan), age of leaders, and a number of members are $55.5 \%$ while other factors described $44.5 \%$.

Testing the effect of all independent variables in the model can be done by conducting a simultaneous test ( $\mathrm{F}$ test). F statistical test shows whether all the independent variables entered into the model have a joint influence on the dependent variable. The model was simultaneously significant since the p-value of $\mathrm{f}$ statistic was $0.00<0.05$ (with $95 \%$ level of confidence $/ \alpha=5 \%$ ). So it can be said that the factors of the previous existence of farmer's community groups as an institution, the year of existence of each farmer's community groups, woman and man participation in each farmer's community groups, the participation of join farmers' group's associations (Gapoktan), age of leader, and number of members simultaneously or jointly have a significant effect on the level of the success of farmer's community group. It is concluded that the independent variables jointly influence the dependent variable.

According to the result depicted (attached data), with the 95\% level of confidence, there are two significant variables, namely the year of existence of each farmer's community groups $\left(\mathrm{X}_{2}\right)$ and the previous existence of farmer's community groups as institutions $\left(\mathrm{X}_{5}\right)$.

According to this model, 2 independent variables significantly influence farmer groups' success with a confidence level of $95 \%$ ( $p$-value 0.05 ). The first is the 
year of existence $\left(X_{2}\right)$. This variable (also significant at the $99 \%$ level) has a positive effect, i.e., the longer its existence, the higher the farmer's community group's success that represents, the higher farmer group's success. While the shorter the existence of the farmer's community groups will be less successful. If the year of existence increases by 1 year, the farmer group's score representing the farmer group's success will increase by 7.329 points. Moreover, if the year of existence decreases by 1 year, the farming community group's score representing the successful farming community group will decrease by 7.329 points.

This result shows that the earlier an organization is formed or, the longer its existence, the stronger the organization, and its better success. On the other hand, more time is needed for younger organizations to consolidate and find patterns to achieve success. This means that older organizations will be better equipped to move forward in economic progress. Therefore, decision-makers can prioritize funding assistance for older organizations than younger ones.

This description is also related to other significant variables, namely the previous existence of a farmer's community group as an institution (subak). The second variable is a farmer's community group's previous existence as an institution (subak) $\left(\mathrm{X}_{5}\right)$. Practically, if a farmer's community group have formerly existed in the form of subak (Institution), it was faster and easier to organize the Institution to be the farmer's community group. Subak already had a previous system proven by time to be a problem-solving system, especially in irrigation. Therefore in the subak case, it was proven that a formerly subak could lead to a better farmer's community group. Even though most of the subak were much more technical oriented institutions rater than economic oriented, they were ready to step up to much more economic orientation.

Therefore, this could be a consideration for a decision-maker to give aid based on whether the organization had the experience of subak. With the continuous experience of subak, the farmer's community group could be prioritized to be given funds. However, the fund could not be solely given without further assessing their economization ability and earlier assistance for economic activities. The positive relation is shown between this dummy variable (previous existence of farmer's community group as subak) and the level of 
success of the farmer's community group. If the farmer's community group were formerly a subak, the farmer's community group's success level would increase by 8.89 points.

Variable combination of Gender (X3). This variable had a negative effect. It means that the organization that comprises both genders, male and female (regardless of proportion), would rather have less success than the organization with only a single-gender. If an organization had both genders as members, the level of success would decrease by 1.008 points and the opposite. If we look at the farmer's community group's proportion, most of the farmer's community groups were single-gender and men dominated. In a farmer's community group consist of both genders, the proportion of women were less than $10 \%$, even very limited in most cases. Bali, indeed, is still a patriarchal society. It might affect the way organizations such as farmer's community group work. Patriarchal society is a kinship system where the lineage follows the men, namely the father and husband, which influences women's role in the family and the local community. This kinship system places women in a lower position than men (Sianipar, 2004). The pattern of patriarchal culture in the farmer's community group would give more strategic access to males when the proportion of women in the organization was low. On the other hand, this condition could be interpreted as the low level of women access and participation in the organization, so the women in the organization had limited access to developing their full potentials. In comparison, we could see from other rural development programs, such as saemaul undong and grameen bank, that women's participation played an important role.

Therefore, we could suggest to the decision-maker that women empowerment in the organization is better to be in a single-gender organization than their individual or small group participation in farmer's community group dominated by men, for it would bring higher success. So we can say the formation of women farmer groups was a good solution to empower women and, at the same, affect the organization's success as there had already been performed by saemaul undong movement. In Indonesia, the women farmer group was relatively new and younger than the farmer's community group. However, the development was rather steady. 
The age of the leader $\left(\mathrm{X}_{1}\right)$ represents the youth participation in the development of the farmer's community group. This variable showed a positive impact on the success of a farmer's community group. If the leader's age increased by 1 year, the successful level would increase by 0.207 points. This result depicted the current picture of the Indonesian organizational style. Young leadership is a relatively new idea in Indonesian culture as young people were considered a lack experience. Therefore young leaders might face the challenge, especially trust from their members. It needs times and occasions to gain trust and might be considered failed at some point in time. Although the idea and issue of youth participation are increasing in Indonesia's urban areas, it seems that the leader should be more experienced in rural organizations. Therefore they are not relatively at their young age.

Moreover, in the rural organization, some rules were rooting back to the socio-cultural pattern. The pattern is divided into more balanced power between members to create group solidity. Although in previous studies, the role of the leader still had a strong influence on the development and dynamics of the farmer's community group but based on the result of this study, there is not enough proof to conclude that the age of the leader had a significant influence to the success of farmer's community group. The leader's age is more personal so that this personal factor pinned to the farmer's community group leader had no significant influence. It might be better than the age factor that was pinned to all farmer's community group members, considering that farmer's community group will be more productive if the stakeholders' average age is at productive age.

The total number of members $\left(\mathrm{X}_{4}\right)$. This variable had a positive effect on the success of the farmer's community group. If the number of members decrease by 1 person, the farmer's community group's success level will decrease by 0.063 points, and the opposite if the one member was added. It suggests that members were assets to the organizations and that they could contribute even just for a relatively slight addition to the success. It also suggests that the rural area's human resources were capable both individually and in an organization. However, there was still not enough proof to conclude that number of members would significantly affect the success of the farmer's community group. This result was similar to the previous studies regarding the number of members in 
the farmer's community group.

The reason for this condition might relate to the socio-cultural aspects of a rural organization in Indonesia. As previously mentioned, in a rural organization such as the farmer's community group, the socio-cultural aspect played a very important role in dividing power among members to create group solidity. The slogan "deliberation to reach consensus" was a principal practice on a farmer's community group daily. Therefore, once this democratic method reached a consensus, every member had the responsibility to obey.

Dummy gapoktan $\left(\mathrm{X}_{6}\right)$. This variable showed a positive relationship with the success of the farmer's community group. If a farmer's community group joined gapoktan, then the success level would increase by 0.265 points. While the

opposite if a farmer's community group did not join gapoktan. Gapoktan was an organization with many of farmer's community groups as members. However, there were not enough results to state that joining the farmer's community group would significantly impact the success of the farmer's community group. This condition was due to certain factors. There was some discussion about whether a farmer's community group's formation was more political than an ideal background. The idea of gapoktan formation was to increase the economization through cooperation between members (farmer's community groups), knowledge sharing, networking, and others. Therefore, there were debates that the farmer's community group was formed to get more project rather than its ideal goals. Gapoktan was not seen as an effort to empower local social capital based on the principles of independence and autonomy. Therefore, gapoktan formation was not positioned in economic development and community independence, leading to sustainable development.

\section{CONCLUSION AND RECOMMENDATION}

Following the results of regression calculations, the value of $\mathrm{R}^{2}=0.555(55 \%)$ is obtained, indicating that the variation in the change in the value of the level of Success of farmer's Community Group (Y) can be explained simultaneously by the factors in equations while other factors described $44.5 \%$. With the $95 \%$ level of confidence, there are two significant variables, namely the year of existence 
of each farmer's community groups $\left(\mathrm{X}_{2}\right)$ and the previous existence of farmer's community groups as institutions (subak) $\left(\mathrm{X}_{5}\right)$. If the year of existence increases by 1 year, the farmer group's score representing the success of the farmer group will increase by 7.329 points and conversely. If the farmer's community group were formerly a subak, the farmer's community group's success level would increase by 8.89 points.

At the same time, we could see evidence that the year of existence had a positive relationship with farmer's community groups' success. The formation of a farmer's community group with or without the initiation of subak previously needed time to develop and achieve success.

This could imply that an organization needs time to be more solid in order to naturally work together. In the case of institutionalizing the organization, or the other way around, the institution also needs time to organize itself to do better and target more significant achievements such as economization. Therefore, the actions or programs between the two could be different.

The existing institutions (subak) that transformed to be farmer's community groups were more independent, and any top-down program should consider the condition of each Institution so it would not break the local wisdom that already existed among the groups. Therefore, the program would bring more success.

While there was not enough evidence to state that young leadership and gender composition would be a success factor to a farmer's community group, it would be too early to say that the youth and gender empowerment are not influencing at all.

Therefore, these two categories (youth participation and gender) could be the target for farmer's community group formation from scratch, rather than combining youth participation and gender composition in an existing institution. Youth participation could not be partial, like youth leadership, since experience and maturity were still a strong part of Indonesia's local wisdom. Women's participation in the farmer's community group couldn't also be presented by woman membership in existing farmer's community groups, especially in men dominated institutions. Therefore, the formation of a women farmer's community group was a suitable strategy. This form of gender organization has also been practiced in the Saemaul Undong movement. It is 
recommended that for further studies, the approach variable for youth participation should include the board of farmer's community group if not the members age rather than solely the leader's age.

The number of members was not proven as a success factor of the farmer's community group. It did not indicate that the bigger or the smaller the farmer's community group would be more successful. Therefore it would not be wise to prioritize the aid solely based on the number of members. Joining gapoktan was also not proven to be significant to the success of the farmer's community group. Even though it was expected to leverage the farmer's community group's success level, the formation of gapoktan was a debate in previous studies. Many argued that gapoktan was beneficial, but more studies revealed that gapoktan formations were formality to get some projects involving funds. Therefore it needed more attention, not just on gapoktan but also on the priority program and leveling, as stages practiced in the Saemaul Undong Movement. However, it would need more effort in Indonesia on a strategic and practical level since Indonesia is a bigger and more diverse country.

For further studies, it is recommended that factors previously mentioned in a hypothesis to be omitted because not available of data, such as the dedication of member and infrastructure of each farmer's community groups also included in the analysis. The smaller scope of data sampling could be applied since secondary data of the population was not available.

\section{REFERENCES}

Anwar, R. P. (2011). Reflection of Saemaul Undong Movement of Indonesia (pp. 117-141). Yogyakarta, Indonesia: Gadjah Mada University.

Bali Provincial Regulation No. 9. (2012). Subak. Denpasar, Indonesia: Provincial Legislature of Bali.

Binswanger, M, H. P., \& Ruttan, V. W. (1978). Induced innovation: Technology, institutions, and development. Baltimore, MD: Johns Hopkins University Press. Brewer, J. D. (1985). Penggunaan tanah tradisional dan kebijakan pemerintah di Bima, Sumbawa Timur (pp. 163-188). Jakarta, Indonesia: Yayasan Obor Indonesia. 
Dewi, K. T. P., Windia, W., \& Diarta, K. S. (2018). Permasalahan subak di daerah pariwisata di subak teges, kecamatan Ubud, kabupaten Gianyar. E-Journal Agribisnis dan Agrowisata, 74), 514-522.

Directorate General of Post Harvest and Marketing. (2014). Laporan Tahunan. Jakarta, Indonesia: Ministry of Agriculture.

Djamhuri, M., \& Rina, Y. (1994). Identification of influencing factors affecting the performance of farmer groups in wetlands (case study in Tapin District). South Kalimantan, Indonesia: Balittra, Ministry of Agriculture, Indonesia.

Hariadi, S. S. (2004). Kajian faktor-faktor yang berpengaruh terhadap keberhasilan kelompok tani sebagai unit usaha/bisnis. yogyakarta, Indonesia: Gadjah Mada University.

Hayami, Y., \& Kikuchi, M. (1987). Dilema ekonomi desa: Suatu pendekatan ekonomi terhadap perubahan kelembagaan di Asia. Jakarta, Indonesia: Yayasan Obor Indonesia.

Horton, P. B., \& Chester, L. H. (1984). Sociology (6th ed). Sidney, Australinea: McGraww-Hill Book.

Huntington, Samuel, P. (1965). Political development and politic decay. World Politics, 17(3), 386-430.

Korean Saemaul Undong Center. (2019). Understanding Saemaul Undong. Seongnam, Korea: Korean Saemaul Undong Center.

Law of the Republic Indonesia No. 19. (2013). Protection and empowerment of farmers.

National Development Planning Agency. (2018). Press conference: Demography bonus 2030-2040: Indonesia strategy related labor and education. Jakarta, Indonesia: National Development Planning Agency.

Park, S. (2009). Analysis of Saemaul Undong: a Korean rural development programme in the 1970s. Asia-Pacific Development Journal, 16(2), 113-140.

Pramadha, R. A., \& Ju, L. J. (2018). Improving community participation in rural community development program: Case study of global Saemaul Undong project in Ponjong village, Gunungkidul regency, Yogyakarta special region, Indonesia. Journal of Saemaulogy, 3(2), 27-72.

Puspitasari, D. C., Satriani, R., \& Pmungkas, S. B. (2019). Capacity building and participatory community through the implementation of Saemaul Undong 
at Bleberan Village, Gunung Kidul District. Journal Sociology Pendidikan Humanis, 4(1), 1-13.

Ravallion, M., \& Chen, S. (2007). China's (uneven) progress against poverty. Journal of Development Economics, 82(1), 1-42.

Scott, R. (2008). Institution and organization. Los Angeles, CA: Sage.

Sianipar, S. J. (2004). Profil perempuan nelayan danau Toba dalam kehidupan keluarga dan masyarakat di desa Lumban Bul Bul, kecamatan Balige, kabupaten Toba Samosir, Sumatera Utara. Bogor, Indonesia: IPB.

Statistics Body of Bali Province. (2019). Retrieved from https://bali.bps.go.id/

Statistics Body of Republic of Indonesia. (2018). Retrieved from https://bps.go.id/

Syahyuti. (2014). Mau ini apa itu, komparasi konsep, teori dan pendekatan dalam pembangunan pertanian dan pedesaan (125 versus 125). Jakarta, Indonesia: Nagakusuma Media Kreatif.

Tjondronegoro, S. M. P. (1999). Memudarnya otonomi desa Dalam: Keping-keping sosiologi dari pedesaan (pp. 15-25). Jakarta, Indonesia: Direktorat Jenderal Pendidikan Tinggi.

Uphoff, N. (1986). Local institutional development: An analytical sourcebook with cases. West Hartford, CT: Kumarian Press.

World Bank. (2020). The World Bank in Republic of Korea. Retrieved from https://www.worldbank.org/en/country/korea 